OPINION PIECE

\title{
The role of ignorance in student-faculty partnerships
}

Sophia Abbot, Higher Education Program, George Mason University, USA.

Contact: sabbot@gmu.edu

In many conversations I've been a part of in the realm of Students as Partners, participants have emphasized the role of differing expertise. Partners come together bringing experiences and strengths that make a greater whole. But I have grown curious about the role of ignorance in partnerships. I am not thinking of students or instructors as ignorant; instead, I am interested in the epistemology of ignorance. Epistemology refers to the study of knowledge itself-so the epistemology of ignorance is the study of the nature of ignorance. In "The Speculum of Ignorance," feminist philosopher Nancy Tuana (2006) writes that:

if we are to fully understand the complex practices of knowledge production and the variety of factors that account for why something is known, we must also understand the practices that account for not knowing, that is, for our lack of knowledge about a phenomenon or, in some cases, an account of the practices that resulted in a group unlearning what was once a realm of knowledge. (p. 2)

In other words, ignorance is not accidental or happenstance, and it is our responsibility to seek out why ignorance about a particular concept or experience exists. I would like to suggest that ignorance plays an essential role in the practice of partnership. Ignorance can either be produced by or disrupted by partnership practices and the way we understand students as knowers.

\section{IGNORANCE AS A BARRIER TO PARTNERSHIP}

Tuana (2006) identifies six different categories of ignorance. Each category relates to power and the decisions we make consciously or subconsciously about what we want to know. The fifth type of ignorance Tuana defines is "ignorance produced by the construction of epistemically disadvantaged identities" (p. 13). By this she means that as a society we define some people as knowers and others as not-knowers or untrustworthy knowers. Tuana is referring to social identities like race and gender and gives the example of women survivors of sexual violence whose accounts are distrusted or dismissed compared with their perpetrators' perspectives because of their difference in power. When perspectives are dismissed (consciously or not) as a result of someone's identity, ignorance is produced.

In the context of academia, the identity of student is constructed as a disadvantaged identity. In this construction, students' perspectives are too frequently brushed off or ignored 
as untrustworthy or uninformed. Student partners in multiple spaces have reflected on this phenomenon of dismissal. Former student partner Hayley Burke (2013) suggested that her perspective "did not carry as much weight as my [faculty] partner's pedagogical or disciplinary logic for their choices within the classroom" (p. 2). Burke reflected that while she brought an "expertise as [a] student" (p. 2) to her partnerships, that expertise was not always valued. Wilson and co-authors (2020) have also shared two examples of students seeking legitimacy as experts. The women students in their team faced critique for how they spoke rather than for the content of their presentation at an academic conference. Other student partners in their team faced obstruction time and again while trying to conduct research interviews with instructors who failed to respect the students as researchers (Wilson et al., 2020). These examples point to the challenges students face not only within their collaborative teams, but also in translating their partnerships and expertise to other spaces. As maggie castor reflects: "the extent to which I was able to fully participate in communities such as professional conferences often depended on faculty members other than my partners taking me seriously as a scholar" (Meacham, castor, \& Felten, 2013, p. 9).

This kind of dismissal has been referred to by other scholars as "epistemic injustice," which Rachel McKinnon (2016) defined as "fail[ing] to believe speakers due to inappropriate prejudices-implicit or explicit" (p. 437). When students are dismissed as knowers, consciously or not, we are enacting epistemic injustice. This injustice is exacerbated when students hold multiple overlapping epistemically disadvantaged identities. Tuana's examples of gender and race are especially relevant here. As another example, Indigenous student Yahlnaaw (2019), when reflecting on her time on the board of a major teaching and learning society, recalls:

I felt that my voice was irrelevant as a student and as an Indigenous person - I was simply there to fulfill the diversity requirement. . . . the dominance of colonial knowledges and pedagogical practices left me feeling I had little room to share my knowledge. (p. 7)

These are the barriers we face in enacting partnership. These prejudices exist on a scale much larger than any one individual. Social context influences and may even erode the trust we work to establish in partnerships in higher education, despite our best intentions. Ignorance is thus produced in partnerships when students' perspectives are filtered through a lens of epistemic distrust.

\section{THE GIFT OF IGNORANCE}

On the flip side of epistemic injustice, however, is epistemic justice. Alise de Bie, Elizabeth Marquis, Alison Cook-Sather, and Leslie Patricia Luqueño (2019) wrote about the possibility of partnerships to reinforce students' legitimacy as knowers, for students to "unlearn that their contributions are not valuable" (p. 40) and partake in the construction of knowledge. One of the foundational principles of partnership is reciprocity, which means the process of partnership has the potential to reconstruct students as trustworthy sources. This transforms partnerships from producing ignorance to producing knowledge. 
Ignorance itself can also play a positive role in partnerships. While nearly all of her categories of ignorance center on the negative consequences of the production of ignorance, Tuana's (2006) final category is called "loving ignorance." Tuana describes this as the way people of vastly different social identities can acknowledge their unbridgeable difference in an act of love. Rather than pretend, for example, that as a white person I will ever truly understand what it is to be Black in the United States, loving ignorance allows me to note this unknowability and yet continue striving to learn.

Partnerships in teaching and learning offer a unique space to foster this kind of loving recognition. While love may feel too intimate to bring into the realm of education, bell hooks (1994) suggests that eros has a legitimate place in the classroom. She writes that,

In reality, special bonds between professors and students have always existed, but traditionally they have been exclusive rather than inclusive. . . I I asked students once: "Why do you feel that the regard I extend to a particular student cannot also be extended to each of you? Why do you think there is not enough love or care to go around?" (p. 199)

hooks emphasized the limitless capacity we have for love in our human relationships. Bringing love to the realm of partnership acknowledges the depth of emotion that is common in these spaces (Felten, 2017). Through loving ignorance, we can encourage collaborations that are not only mutually empowering (Abbot, 2017), but also joy-filled, vulnerable, and continually evolving. We thus give permission to one another to grow and change through partnership, striving always to see each other more truly.

\section{ACKNOWLEDGEMENTS}

I'd like to offer my deepest gratitude to Stephen Bloch-Schulman, who first introduced me to Tuana's work and spent many hours talking with me about ignorance, knowledge, power, and higher education. Thank you to my reviewers for their generous and immensely helpful feedback. And thank you, Kelly Matthews, for encouraging me to put my thoughts into writing.

\section{NOTE ON CONTRIBUTOR}

Sophia Abbot is a doctoral student in Higher Education at George Mason University (USA). She has studied and practiced partnership in its many forms for nearly ten years, and looks forward to continuing to advance the principles of this work throughout her career.

\section{REFERENCES}

Abbot, S. (2017). Book review of Teaching to transgress: Education as the practice of freedom. International Journal for Students as Partners, 1(2). https://doi.org/10.15173/ijsap.v1i2.3230 
Burke, H. (2013). Legitimizing student expertise in student-faculty partnerships. Teaching and Learning Together in Higher Education, 1(10). https://repository.brynmawr.edu/tlthe/vol1/iss10/6

de Bie, A., Marquis, E., Cook-Sather, A., \& Luqueño, L. P. (2019). Valuing knowledge(s) and cultivating confidence: Contributions of student-faculty pedagogical partnerships to epistemic justice. In J. Hoffman, P. Blessinger, \& M. Makhanya (Eds.), Innovations in Higher Education Teaching and Learning (vol. 16, pp. 35-48). Emerald Publishing Limited. https://doi.org/10.1108/S2055-364120190000016004

hooks, b. (1994). Teaching to transgress: Education as the practice of freedom. Routledge.

Felten, P. (2017). Emotion and partnerships. International Journal for Students as Partners, 1(2). https://doi.org/10.15173/ijsap.v1i2.3070

McKinnon, R. (2016). Epistemic injustice. Philosophy Compass, 11(8), 437-446. https://doi.org/10.1111/phc3.12336

Meacham, M., castor, m., \& Felten, P. (2013). Partners as newcomers: Mixed-role partnerships as communities of practice. Teaching and Learning Together in Higher Education, 1(10). http://repository.brynmawr.edu/tlthe/vol1/iss10/5

Tuana, N. (2006). The speculum of ignorance: The women's health movement and epistemologies of ignorance. Hypatia, 21(3), 1-19. http://dx.doi.org/10.1111/j.15272001.2006.tb01110.x

Wilson, S., Phillips, J., Meskhidze, H., Lockard, C., Felten, P., McGowarn, S., \& Bloch-Schulman, S. (2020). From novelty to norm. In L. Mercer-Mapstone \& S. Abbot (Eds.), The power of partnership: Students, staff, and faculty revolutionizing higher education (pp. 159-170). Center for Engaged Learning Open Access Book Series. https://doi.org/10.36284/celelon.oa2

Yahlnaaw (2019). T'aats'iigang - Stuffing a jar full. International Journal for Students as Partners, 3(2), 6-10. https://doi.org/10.15173/ijsap.v3i2.4081 